\title{
Thiazides and hypokalaemia in diabetic ketoacidosis
}

\author{
K. G. M. M. Alberti \\ M.A., D.Phil., B.M., B.Ch.
}

\author{
T. D. R. HocKADAY \\ F.R.C.P., D.Phil.
}

Nuffield Department of Medicine and Division of Medicine, The Radcliffe Infirmary, Oxford

\begin{abstract}
Summary
In a series of forty-one episodes of diabetic coma or pre-coma, three patients had plasma potassium values of less than $3.0 \mathrm{mEq} / \mathrm{l}$. All three had been taking thiazide diuretics with only one receiving oral potassium supplements. None was previously known to be diabetic, representing $18 \%$ of the new diabetics in the series. The mean plasma potassium for the other new diabetics was $4.7 \pm 0.2 \mathrm{mEq} / \mathrm{l}$. These findings emphasize that adequate potassium supplements should be given with thiazide diuretics to diabetic subjects and to those with an increased risk of developing the disease.
\end{abstract}

\section{Introduction}

Diabetic coma and pre-coma are still associated with a significant mortality, approximately $8 \%$ in series from general hospitals (Beigelman, 1971; Alberti \& Hockaday, 1972). Precipitating factors include infection and deficient insulin dosage although in many subjects no precipitant can be found. Obviously, detection of avoidable factors is of value.

Potassium depletion can cause glucose intolerance (Sagild, Andersen \& Andreasen, 1961). Thiazide diuretics may cause both potassium depletion and deterioration in glucose tolerance but their effects on normal subjects are controversial (Breckenridge et al., 1967; Goldner, Zarowitz \& Akgun, 1960; Rapoport \& Hurd, 1964). However, studies in latent or mild diabetics clearly show deleterious effects of chlorothiazide on carbohydrate metabolism (Bojanowicz \& Zubowski, 1967). It has been suggested that chlorthalidone and frusemide cause only mild potassium depletion with little or no effect upon glucose intolerance or insulin secretion (Healy et al., 1970) although diabetes mellitus has been reported after chlorthalidone therapy (Andersen \& Persson, 1968; Moret, 1965).

We present below case reports of three previously undiagnosed diabetics admitted with hypokalaemia and severe diabetic ketoacidosis all of whom were taking thiazide diuretics. These data are reported to emphasize, first, the need to pay particular notice to potassium therapy when thiazides are given to diabetics and those at risk of developing the disease and, second, the possible diabetogenic effect of these compounds.

\section{Subjects}

In the past 15 months thirty-eight patients have been admitted to this hospital with forty-one episodes of severe ketoacidosis, defined as uncontrolled diabetes of a severity necessitating urgent intravenous fluid, electrolyte and insulin therapy with total ketone bodies (acetoacetate plus 3hydroxybutyrate) of more than $3 \mathrm{mEq} / \mathrm{l}$. In seventeen $(45 \%)$ of these patients diabetes had not previously been diagnosed. Only three had been taking thiazide diuretics, and only one was receiving any oral potassium supplement. One other of the new diabetics was also receiving a thiazide diuretic but presented with normal serum potassium, while only one of the twenty-one known diabetics was on chronic diuretic therapy.

\section{Case 1}

S.C. (R.I. No: 494544), a 52-year-old housewife, was admitted in diabetic 'coma'. Two months previously she had been prescribed Durophet (an amphetamine preparation) and chlorthalidone, 100 $\mathrm{mg} /$ day, as well as a reducing diet, because of obesity. At that time the presence of diabetes mellitus had not been detected. She lost $14 \mathrm{lb}$ in weight during the 2 months but became thirsty and drank excessively after 1 month of treatment. The day before admission muscular weakness and lassitude developed, and she was drowsy and vomiting during the final $12 \mathrm{hr}$. There was no family history of diabetes nor past personal history of serious illness.

On admission she was dehydrated and ketotic with air hunger. Blood pressure was $105 / 60 \mathrm{mmHg}$. Some details of blood biochemistry and treatment are given in Table 1 . Blood urea was $85 \mathrm{mg} / 100 \mathrm{ml}$. Because of the early knowledge of hypokalaemia bicarbonate was given cautiously, $60 \mathrm{mEq}$ at $2 \mathrm{hr}$ and again $3 \mathrm{hr}$ after starting insulin. In the first $3 \frac{1}{2} \mathrm{hr}$ she received $2 \frac{1}{2} 1$ of 'normal' saline and was then changed to $0.54 \%$ saline.

She became normally conscious after $2 \mathrm{hr}$ of treatment and indeed was excessively talkative until she fell asleep around the sixth hour. Next morning a right hemiparesis with dysphasia was present but these signs had greatly improved 1 month later when she was talking normally and could walk with assistance. She was still on insulin treatment. 
TABLE 1. Biochemical findings and treatment

\begin{tabular}{|c|c|c|c|c|c|c|c|c|}
\hline & $\begin{array}{c}\text { Time after } \\
\text { insulin } \\
\text { commenced } \\
(\mathrm{hr})\end{array}$ & $\begin{array}{c}\text { Blood } \\
\text { glucose } \\
(\mathrm{mg} / 100 \mathrm{ml})\end{array}$ & $\begin{array}{c}\text { Total ketone } \\
\text { bodies } \\
(\mathrm{mEq} / \mathrm{l})\end{array}$ & $\mathrm{pH}$ & $\begin{array}{c}\text { Plasma } \\
\text { sodium } \\
(\mathrm{mEq} / \mathrm{l})\end{array}$ & $\begin{array}{c}\text { Plasma } \\
\text { potassium } \\
(\mathrm{mEq} / \mathrm{l})\end{array}$ & $\begin{array}{l}\text { Cumulative } \\
\text { insulin } \\
\text { (units) }\end{array}$ & $\begin{array}{l}\text { Cumulative I.v. } \\
\text { potassium } \\
(\mathrm{mEq})\end{array}$ \\
\hline Case 1 & $\begin{array}{r}0 \\
1 \\
3 \\
5 \\
12\end{array}$ & $\begin{array}{r}1200 \\
970 \\
600 \\
315 \\
225\end{array}$ & $\begin{array}{l}17 \cdot 6 \\
12 \cdot 4 \\
10 \cdot 7 \\
12 \cdot 2 \\
-\end{array}$ & $\begin{array}{c}7 \cdot 04 \\
\overline{7 \cdot 18} \\
\overline{7 \cdot 42}\end{array}$ & $\begin{array}{r}122 \\
135 \\
144 \\
140\end{array}$ & $\begin{array}{l}2.9 \\
1.4 \\
2.0 \\
4 \cdot 5 \\
4 \cdot 9\end{array}$ & $\begin{array}{l}100 \\
100 \\
172 \\
172 \\
172\end{array}$ & $\begin{array}{r}0 \\
7 \\
91 \\
234 \\
307\end{array}$ \\
\hline Case 2 & $\begin{array}{r}0 \\
1 \\
5 \\
14 \\
24\end{array}$ & $\begin{array}{l}700 \\
410 \\
225 \\
330 \\
245\end{array}$ & $\begin{array}{l}5 \cdot 1 \\
3 \cdot 1 \\
0 \cdot 5 \\
0 \cdot 2\end{array}$ & $\begin{array}{l}7 \cdot 41 \\
- \\
- \\
-\end{array}$ & $\begin{array}{r}140 \\
144 \\
134 \\
134\end{array}$ & $\begin{array}{l}2 \cdot 8 \\
2 \cdot 6 \\
3 \cdot 2 \\
4 \cdot 1 \\
4 \cdot 2\end{array}$ & $\begin{array}{r}80 \\
80 \\
96 \\
112 \\
144\end{array}$ & $\begin{array}{r}0 \\
7 \\
65 \\
117 \\
156\end{array}$ \\
\hline Case 3 & $\begin{array}{r}0 \\
1 \\
5 \\
11 \\
17 \\
24\end{array}$ & $\begin{array}{r}720 \\
715 \\
115 \\
140 \\
- \\
-\end{array}$ & $\begin{array}{l}16 \cdot 0 \\
- \\
- \\
- \\
1 \cdot 3\end{array}$ & $\begin{array}{l}7 \cdot 15 \\
- \\
- \\
-\end{array}$ & $\begin{array}{r}135 \\
130 \\
126 \\
- \\
-\end{array}$ & $\begin{array}{l}2 \cdot 0 \\
2 \cdot 0 \\
2 \cdot 4 \\
1 \cdot 8 \\
3 \cdot 0 \\
-\quad\end{array}$ & $\begin{array}{l}100 \\
200 \\
200 \\
208 \\
208 \\
208\end{array}$ & $\begin{array}{r}0 \\
0 \\
39 \\
39 \\
91 \\
117\end{array}$ \\
\hline
\end{tabular}

\section{Case 2}

J.O. (R.I. No: 43431), a 65-year-old female, was admitted as an emergency in diabetic 'coma'. Mild hypertension had been found 6 years before, and for the last 6 months she had been treated with chlorthalidone $100 \mathrm{mg} /$ day and methyldopa, $250 \mathrm{mg}$ thrice daily. For some weeks she had noticed mild weight loss, with nocturia and polyuria for 3 weeks, thirst for 1 week, and vomiting for 2 days. There was no previous indication that she had diabetes.

On admission she was conscious with normal respiration and blood pressure $160 / 100$, but markedly dehydrated. Again the essentials of biochemistry and treatment are shown in Table 1. Blood urea was $88 \mathrm{mg} / 100 \mathrm{ml}$. She was not given bicarbonate and after $2 \frac{1}{2} 1$ of 'normal' saline in $6 \mathrm{hr}$ the intravenous fluid was changed to $4 \%$ glucose in one-fifth 'normal' saline.

She made an uneventful recovery and remains on insulin treatment.

\section{Case 3}

K.R. (R.I. No: 361141), a 48-year-old female, was admitted with the complaints of loss of appetite, vomiting, thirst and polyuria for 1 week, with abdominal pain and nausea and drowsiness on the day of admission. She was not previously known to be diabetic and there was no family history of diabetes. Five months previously she had been investigated for vague malaise. The blood glucose was then normal, while an enlarged liver, atrophic gastritis, achlorhydria and a BSP retention of $16 \%$ were also discovered. She had been treated with diuretics for 2 years, and after her last admission she took bendrofluazide $25 \mathrm{mg}$ b.d. and 'Slow K', Ciba, one tablet b.d. (potassium chloride, 0.6.g b.d.).
On admission she was dehydrated with marked air 을 hunger and a palpable liver edge; pulse was $100 / \mathrm{min} \rightarrow$ and BP 120/80 mmHg. Blood values and treatment are summarized in Table 1 . The 3-hydroxybutyrate/ acetoacetate ratio was exceptionally high at $32 \stackrel{\text { g }}{2}$ (corroborated by a negative Ketostix). Blood glucose fell to $115 \mathrm{mg} / 100 \mathrm{ml}$ by $5 \mathrm{hr}$ after treatment bu plasma potassium was $1.8 \mathrm{mEq} / 110 \mathrm{hr}$ after insuli and still only $2.9 \mathrm{mEq} / \mathrm{l} 4$ days later. Difficulty was encountered with intravenous therapy, so that onfy mild potassium replacement was achieved (Table 1). After incision of a perianal abscess she made an uneventful recovery and was discharged on 32 units soluble insulin and 20 units isophane insulin per day.

\section{Discussion}

Severe hypokalaemia has been described in a minority of diabetics since this condition was first $\bar{T}$ recognized (Abramson \& Arky, 1966; Sheldon \& 3 . Pyke, 1968), although it was a notable feature of the 'epidemic' of severe ketoacidosis reported in association with an influenza epidemic (Watkins et al., 1970). In three recent series involving a total of 164 episodes no initial hypokalaemia was noted 음 (Cohen et al., 1960; Cryer \& Daughaday, 1969; $>$ Malins, 1968) while Beigelman reported serum potassium values of less than $3.5 \mathrm{mEq} / \mathrm{l}$ in only $4 \%$ o of a series of 327 cases (Beigelman, 1971). In a recent Californian series (twenty-five episodes of 0 ketoacidosis) (Kiraly, Becker \& Williams, 1970) the only patient who developed symptoms of hypokalaemia during treatment (serum potassium 1.60 $\mathrm{mEq} / \mathrm{l})$ had been on thiazides, and also had the $\Phi_{\overparen{D}}$ lowest initial potassium concentration $(3.3 \mathrm{mEq} / \mathrm{l})$. Initial or severe hypokalaemia is of grave prognostic significance (Abramson \& Arky, 1966; Watkins et al., 1970; Holler, 1946). 
The occurrence of hypokalaemia in three of seventeen newly diagnosed diabetics presenting with severe diabetic ketoacidosis is of significance when taken in conjunction with the fact that all three were taking thiazide diuretics, two without potassium supplementation. The initial mean plasma potassium in the other fourteen subjects was $4.7 \pm 0.2$ (SE) $\mathrm{mEq} / \mathrm{l}$ with the three thiazide patients all more than $2 \mathrm{SD}$ below this value. It is impossible to decide whether these subjects were mild undiagnosed diabetics or non-diabetics before thiazide therapy and whether the thiazide or the hypokalaemia precipitated the severe ketoacidosis. In favour of the thesis that these subjects were all potential diabetics is the finding that all required continued substantial insulin therapy even after correction of hypokalaemia and cessation of the thiazides. Vomiting before admission was not confined to these three, nor was it severe enough to cause this degree of hypokalaemia.

Severe ketoacidosis has infrequently been reported as a hazard of thiazide therapy (Sugar, 1961). More often transient hyperglycaemia occurs, though it is not rare for patients with hyperosmolar nonketotic hyperglycaemia 'coma' to be receiving treatment with thiazides (Portier et al., 1968; Solvsteen, Olsen \& Hansen, 1968). It is of interest that $125 \mathrm{mg}$ chlorthalidone/day with potassium supplementation caused significant hyperglycaemia in $91 \%$ of a series of non-diabetic mental patients, and they also showed reduced blood levels of insulin-like activity and reduced responsiveness of adipose tissue to insulin (Dobrzanski, 1969) although Nicole \& Pulver found effects only in diabetic subjects but not in normal subjects (Nicole \& Pulver, 1962).

However, potassium depletion is known to be present even in well controlled diabetics (Telfer, 1966). The danger of provoking further potassium loss emphasizes the need for prescription of adequate amounts of supplementary oral potassium to all who receive potassium-losing diuretics if these patients have the least likelihood of developing diabetes. Observations of potassium loss in healthy subjects may not apply to patients in the yet undiagnosed phases of a disease.

\section{Acknowledgments}

We thank Professor P. B. Beeson and Dr S. C. Truelove for allowing us to study patients admitted under their care, and the NHS for a research grant. K. G. M.M. A. gratefully acknowledges financial assistance from the Wellcome Trust. We should also like to thank the Department of Clinical Biochemistry for their helpful collaboration.

\section{References}

Abramson, E. \& Arky, R. (1966) Diabetic acidosis with initial hypokalaemia. Journal of the American Medical Association, 196, 401.

Alberti, K.G.M.M. \& Hockaday, T.D.R. (1972) In preparation.
Andersen, O.O. \& Persson, I. (1968) Carbohydrate metabolism during treatment with chlorthalidone and ethacrynic acid. British Medical Journal, 2, 798.

Beigelman, P.M. (1971) Severe diabetic ketoacidosis (diabetic 'coma'). Diabetes, $20,490$.

Bojanowicz, K. \& ZubowsKi, A. (1967) Beziehungen zwischen Kalium - und Kohlenhydratstoff wechselstörungen bei Diabetes Mellitus. Diabetologia, 3, 500.

Breckenridge, A., Welborn, T.A., Dollery, C.T. \& Fraser, R. (1967) Glucose tolerance in hypertensive patients on long-term diuretic therapy. Lancet, $\mathbf{i}, 61$.

Cohen, A.S., Vance, V.K., Runyan, J.W. \& Hurwitz, D. (1960) Diabetic acidosis: an evaluation of the cause, course and therapy of 73 cases. Annals of Internal Medicine, 52, 55.

Cryer, P.E. \& Daughaday, W.H. (1969) Diabetic ketosis: Elevated serum glutamic-oxaloacetic transaminase (SGOT) and other findings determined by multi-channel chemical analysis. Diabetes, 18, 781 .

DoBRZANSKI, J. (1969) Investigation on the incidence of so-called 'chlorthalidone diabetes' in mentally-ill patients. Endokrynologia Polska (Warszawa), 20, 391.

Goldner, M.G., Zarowitz, H. \& AkgüN, S. (1960) Hyperglycaemia and glycosuria due to thiazide derivatives administered in diabetes mellitus. New England Journal of Medicine, 262, 403.

Healy, J.J., McKenna, T.D., Canning, B. ST.J., Brien, T.G., Duffy, G.J. \& Muldowney, F.P. (1970) Body composition changes in hypertensive subjects on longterm oral diuretic therapy. British Medical Journal, 1, 716.

Holler, J.W. (1946) Potassium deficiency occurring during the treatment of diabetic acidosis. Journal of the American Medical Association, 131, 1186.

Kiraly, J.F., Becker, C.E. \& Williams, H.E. (1970) Diabetic ketoacidosis - a review of cases at a University Medical Center. California Medicine, 112, 1.

Malins, J.M. (1968) Clinical Diabetes Mellitus. Eyre and Spottiswoode, London.

MORET, B. (1965) Zur diabetogenen Wirkung der Saluretica. Deutsche medizinische Wochenschrift, 90, 1136.

Nicole, J.C. \& Pulver, W. (1962) Hyperglykamischer Effekt durch Salidiruetica bei Diabetes Mellitus. Helvetica medica Acta, 29, 556.

Portier, A., Chatelain, P., Caillar, B., Irr, P. \& Portier, $\mathrm{CH}_{\mathrm{H}}$ (1968) Coma hyperglycémique sans cétose, avec déshydration, déplétion chloro-sodique et potassique, après traitement par salidiuretiques chez des malades non diabétiques. Semaine Hopital Paris, 44, 3017.

RAPOPORT, M.I. \& HuRD, H.F. (1964) Thiazide-induced glucose intolerance treated with potassium. Archives of Internal Medicine, 113, 405.

Sagild, U., Andersen, V. \& Andreasen, P.B. (1961) Glucose tolerance and insulin responsiveness in experimental potassium depletion. Acta medica scandinavica, $169,243$.

Sheldon, J. \& Pyke, D.A. (1968) Clinical Diabetes (Ed. by W. G. Oakley, D. A. Pyke and K. W. Taylor). Blackwell Scientific Publications, Oxford.

Solvsteen, P., Olsen, V.V. \& Hansen, E.L. (1968) Diabetic coma without ketoacidosis. Acta medica scandinavica, 184, 83.

SUGAR, S.J.N. (1961) Diabetic acidosis during chlorothiazide therapy. Journal of the American Medical Association, 175, 618.

Telfer, N. (1966) Exchangeable potassium in diabetes. Metabolism, 15, 502.

Watkins, P.J., Soler, N.G., Fitzgerald, M.G. \& Malins, J.M. (1970) Diabetic ketoacidosis during the influenza epidemic. British Medical Journal, 4, 89. 